\title{
Pemberian jus belimbing Demak (Averrhoe carambola I) berpengaruh terhadap penurunan tekanan darah sistolik dan diastolik pada penderita hipertensi ${ }^{1}$
}

Heri Sulistiyono ${ }^{2}$, M.Isnawati ${ }^{2}$

\begin{abstract}
Backgrounds: Hypertension is the main risk factor for cardiovascular disease that is the primer cause of death in the world. Hypertension is associated with food pattern that is high in sodium and low in potassium. Demak's starfruit is a high potassium food that has negative effect on high blood pressure.

Objective: To find out the effect of Demak's starfruit juice for decreasing of systolic and diastolic blood pressure in patient with hypertension.

Method: This study was randomized control trial (RCT) design in two groups. The first group was treated with $500 \mathrm{ml}$ Demak's starfruit juice derived from 280 grams Demak's starfruit containing $425 \mathrm{mg}$ of potassium, $11 \mathrm{mg}$ of calcium and $2,8 \mathrm{mg}$ of magnesium for 7 days and the second group was a control with starfruit essence. The subjects in this study 34 persons. The subject had systolic blood pressure $140-160 \mathrm{mmHg}$ and diastolic $90-100 \mathrm{mmHg}$. Intake of sodium, potassium, calcium and magnesium during research was observed with $2 \times 24$ hour food recall method. Statistical analysis used here was Kolmogorov-Smirnov, paired t-test, independent t-test and anakova.

Results: There was significant decreases in systolic and diastolic blood pressure of 19,71 $\pm 7,39$ and 14,41 \pm 8,08 in

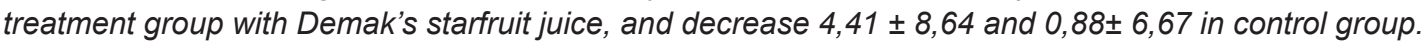

Conclusion: Demak's starfruit juice (Averrhoe carambola I) influence on the decrease of systolic and diastolic blood pressure.
\end{abstract}

KEY WORDS hypertension, Demak's starfruit, pottasium

\section{PENDAHULUAN}

Hipertensi merupakan penyakit mematikan yang banyak diderita, namun jarang disadari karena tidak menampakkan gejala - gejala yang nyata. Biasanya hipertensi ditemukan secara kebetulan (1). Menurut WHO, dari $50 \%$ penderita hipertensi yang terdeteksi, hanya $25 \%$ mendapat pengobatan, dan hanya $12,5 \%$ dapat diobati dengan baik (2). Berdasarkan Survei Kesehatan Rumah Tangga (SKRT) tahun 2004, diketahui bahwa prevalensi hipertensi di Pulau Jawa sebesar 41,9\%, dengan kisaran di masing-masing provinsi $36,6-47,7 \%$. Prevalensi di perkotaan $39,9 \%$ dan di pedesaan $44,1 \%$. Di Jawa Tengah, prevalensi kejadian hipertensi sebesar $6,0 \%$ pada pria dan $11,6 \%$ pada wanita. Berdasarkan laporan dari rumah sakit dan puskesmas di Jawa Tengah tahun 2005, kasus tertinggi hipertensi terdapat di Kabupaten Klaten sebanyak 41.126 kasus $(10,14 \%)(2,3)$. Hipertensi sering didefinisikan sebagai tekanan darah sistolik lebih dari atau sama dengan $140 \mathrm{mmHg}$ dan atau tekanan darah diastolik lebih dari atau sama dengan $90 \mathrm{mmHg}$, diukur sedikitnya pada tiga saat yang berbeda atau bila pasien mengonsumsi obat antihipertensi $(4,5)$.

Hipertensi merupakan faktor risiko utama kardiovaskuler yang merupakan penyebab utama kematian di seluruh dunia (6). Analisis pola penyakit penyebab kematian di Indonesia, diperoleh hasil bahwa penyebab utama (underlying cause) kematian di Indonesia adalah penyakit sistem sirkulasi yaitu penyakit jantung dan pembuluh darah yang sebagian besar bermula dari hipertensi (3). Hipertensi merupakan penyakit yang dapat dicegah jika faktor risiko dapat dikendalikan. Beberapa faktor risiko hipertensi berkaitan dengan gaya hidup masyarakat modern seperti stres, kurang beraktivitas, merokok, makanan tinggi kadar lemak, asupan natrium yang tinggi, kurangnya asupan kalium dan serat, serta konsumsi alkohol yang berlebih (7). Pengendalian hipertensi harus didasari partisipasi dan pemberdayaan masyarakat, dengan mendorong kemandirian masyarakat untuk hidup sehat dengan banyak mengonsumsi buah dan sayuran yang mengandung unsur mineral penting pencegah terjadinya hipertensi diantaranya kalium, kalsium, dan magnesium (8).

Belimbing Demak (Averrhoe carambola I) merupakan varietas buah belimbing yang penyebarannya sudah meluas di Jawa Tengah dan kualitas hasil buahnya sudah seragam (9). Belimbing Demak (Averrhoe carambola I) merupakan bahan makanan yang mengandung sumber mineral penting pencegah hipertensi yaitu kalium, kalsium, dan magnesium. Berdasarkan uji laboratorium, dalam 280

\footnotetext{
Dipresentasikan pada International Dietetic Update pada tanggal 1517 Oktober 2009 di Yogyakarta kerjasama dengan Asosiasi Dietisien Indonesia, Jurnal Gizi Klinik Indonesia, dan Prodi Gizi Kesehatan FKUGM serta didanai oleh Pendidikan Tinggi Kementerian Pendidikan Nasional.

2 Program Studi Ilmu Gizi Fakultas Kedokteran Universitas Diponegoro
} 
gram buah belimbing Demak terdapat kalium sebesar 425 mg, kalsium sebesar $11 \mathrm{mg}$, dan magnesium sebesar 2,8 mg (10). Kalium mempunyai efek negatif terhadap penurunan tekanan darah (11). Hasil penelitian di Semarang tahun 2007 diperoleh hasil bahwa dengan pemberian buah yang banyak mengandung kalium seperti melon, pepaya, dan mangga memberikan efek menurunkan tekanan sistolik dan diastolik secara signifikan (12).

Tujuan dari penelitian ini adalah untuk mengetahui pengaruh pemberian jus buah belimbing terhadap penurunan tekanan darah sistolik dan diastolik pada penderita hipertensi. Hasil dari penelitian ini diharapkan dapat memberikan informasi tentang kandungan kalium dalam buah belimbing yang dapat berpengaruh terhadap penurunan tekanan darah sistolik dan diastolik pada penderita hipertensi, dan dapat dijadikan rujukan tambahan untuk penelitian berikutnya.

\section{BAHAN DAN METODE}

Penelitian ini dilaksanakan di Dukuh Badran, Desa Troketon, Kecamatan Pedan, Kabupaten Klaten pada bulan Oktober 2008. Penelitian ini merupakan penelitian eksperimen dengan metode randomized control trial (RCT). Kelompok perlakuan diberikan jus belimbing Demak, sedangkan kelompok kontrol diberikan sirup rasa belimbing. Populasi terjangkau pada penelitian ini adalah masyarakat umum di Dukuh Badran, Desa Troketon, Kecamatan Pedan, Kabupaten Klaten yang berumur 40 - 60 tahun dan termasuk dalam kategori hipertensi ringan yang memiliki tekanan darah sistolik 140 - $160 \mathrm{mmHg}$ dan atau diastolik 90-100 $\mathrm{mmHg}$.

Jumlah subjek dalam penelitian ini berjumlah 34 orang untuk kedua kelompok yang dihitung menggunakan rumus uji beda rata - rata berpasangan dengan tingkat kemaknaan 95\% ( $\alpha=0,05)$ dan standar deviasi (Sd) 14 $\mathrm{mmHg}$ (13). Pengambilan subjek penelitian dilaksanakan secara purposive sampling secara door to door, di mana proses pengambilan subjek ini dilakukan dengan memasukkan semua subjek yang memenuhi kriteria inklusi tertentu sampai jumlah sampel yang diperlukan terpenuhi. Kriteria inklusi dalam penelitian ini adalah berumur 40-60 tahun, termasuk dalam kategori hipertensi ringan yang mempunyai tekanan darah sistolik 140-160 $\mathrm{mmHg}$ dan diastolik 90-100 mmHg, tidak mengonsumsi alkohol, tidak merokok, tidak mempunyai penyakit komplikasi atau sedang dalam pengobatan antihipertensi. Kriteria eksklusi dalam penelitian ini adalah subjek menderita penyakit komplikasi sehingga dirawat di rumah sakit, subjek meninggal dunia, dan subjek tidak mengonsumsi jus belimbing yang diberikan.

Variabel independen dalam penelitian ini adalah kelompok perlakuan, yaitu kelompok jus dan kelompok kontrol, variabel dependen adalah tekanan darah sistolik dan diastolik, variabel luar adalah konsumsi natrium, kalium, kalsium, dan magnesium yang diukur dengan metode food recall selama 2 × 24 jam.

Tekanan darah adalah kekuatan yang dihasilkan oleh darah terhadap setiap satuan luas dinding pembuluh darah yang diukur dalam posisi duduk bersandar, setelah beristirahat selama 5 menit dengan kaki menyentuh lantai dan tangan sejajar dengan jantung dengan menggunakan spigmomanometer air raksa yang dilakukan oleh perawat yang sudah terlatih dalam melakukan pengukuran tekanan darah. Pengukuran tekanan darah dilakukan dua kali yaitu pada awal sebelum perlakuan dan akhir setelah perlakuan baik pada kelompok jus atau kelompok kontrol. Pengukuran tekanan darah pertama dilakukan 5 menit sebelum perlakuan dan selang waktu 60 menit setelah pemberian perlakuan untuk evaluasi. Data tekanan darah yang digunakan merupakan hasil rata-rata pengukuran.

Konsumsi natrium, kalium, kalsium, dan magnesium didefinisikan sebagai jumlah natrium, kalium, kalsium, dan magnesium yang dikonsumsi selama penelitian kemudian dihitung rata - rata per hari yang diukur dengan menggunakan metode food recall selama $2 \times 24$ jam kemudian dianalisis dengan menggunakan program food processor 3 . Data yang diperoleh dalam ukuran rumah tangga, kemudian dikonversikan kedalam satuan milligram. Pemberian jus belimbing didefinisikan sebagai jumlah jus belimbing yang dikonsumsi oleh subjek sebanyak $500 \mathrm{ml}$ yang dibuat dari 280 gram buah belimbing jenis Demak, 300 ml air, dan 13 gram gula dengan tingkat kematangan belimbing Demak seragam dan diberikan pada siang hari sesaat setelah pembuatan jus selesai selama 7 hari berturut-turut. Belimbing Demak berasal dari penjual yang sama yang didapat langsung dari Demak. Cara pembuatan jus belimbing yaitu dengan memblender belimbing Demak sebanyak 280 gram dengan air $300 \mathrm{ml}$, dan gula 13 gram selama 3 menit kemudian disaring dengan kain kasa. Hasil saringan berupa jus belimbing Demak sebanyak $500 \mathrm{ml}$ yang mengandung kalium sebesar $425 \mathrm{mg}$, kalsium $11 \mathrm{mg}$, dan magnesium sebesar 2,8 mg berdasarkan uji laboratorium dengan menggunakan metode analyse absorbance spectofotometri (ASS) langsung diberikan kepada subjek sesaat setelah semua pembuatan jus belimbing selesai. Cara pengonsumsian subjek yaitu jus belimbing yang diberikan langsung diminum. Untuk kelompok kontrol diberikan sirup rasa belimbing sebanyak $500 \mathrm{ml}$, yang terbuat dari air sebanyak $450 \mathrm{ml}$, sirup rasa belimbing $50 \mathrm{ml}$, dan gula pasir sebanyak 13 gram. Sirup belimbing langsung diberikan pada subjek kelompok kontrol segera setelah dibuat, pada siang hari selama 7 hari berturut - turut. Kedua kelompok penelitian tidak mengetahui jenis minuman yang dikonsumsi, sedangkan peneliti mengetahuinya (single blinding).

Data yang dikumpulkan dalam penelitian ini adalah data identitas subjek yang meliputi nama, umur, jenis kelamin yang diperoleh dari pengisian formulir dan tanya 
jawab, data karakteristik subjek yang meliputi kebiasaan olah raga dan riwayat hipertensi dalam keluarga, data antropometri meliputi tinggi badan dan berat badan, data tekanan darah subjek yang diperoleh dengan melakukan pengukuran secara langsung dengan menggunakan sphygmomanometer air raksa yang diukur oleh perawat, data konsumsi natrium, kalium, kalsium, dan magnesium subjek yang diperoleh dengan menggunakan metode food recall 2 x 24 jam yang dilakukan oleh peneliti, dan data tingkat kepatuhan serta daya terima subjek terhadap pemberian jus belimbing dilakukan dengan melakukan observasi secara langsung kepada subjek.

Analisis data dilakukan dengan menggunakan program komputer. Analisis univariat untuk menguji kenormalan data dengan Kolmogorov-Smirnov, analisis bivariat menggunakan uji paired t-test, dan analisis multivariat menggunakan uji anakova dengan tingkat kemaknaan statistik di mana $Z=1,64$ pada $\alpha=0,05$ (dengan derajat kemaknaan $95 \%$ ). Penelitian ini telah mendapatkan persetujuan dari Komisi Etik Penelitian Kesehatan Fakultas Kedokteran Universitas Diponegoro dan RS Dr. Kariadi Semarang.

\section{HASIL}

\section{Karakteristik subjek penelitian}

Subjek dalam penelitian ini sebagian besar berjenis kelamin perempuan, berumur 40 - 49 tahun, mempunyai
Tabel 1. Distribusi frekuensi beberapa karakteristik subjek

\begin{tabular}{|c|c|c|c|}
\hline \multirow{2}{*}{$\begin{array}{c}\text { Karakteristik } \\
\text { Subyek }\end{array}$} & $\begin{array}{c}\text { Perlakuan } \\
(\mathrm{n}=17)\end{array}$ & $\begin{array}{l}\text { Kontrol } \\
(\mathrm{n}=17)\end{array}$ & \multirow[t]{2}{*}{${ }^{*} p$} \\
\hline & $\mathbf{n}$ & $\mathbf{n}$ & \\
\hline \multicolumn{4}{|l|}{ Jenis kelamin } \\
\hline Laki-laki & 5 & 8 & \multirow[t]{2}{*}{0,170} \\
\hline Perempuan & 12 & 9 & \\
\hline \multicolumn{4}{|l|}{ Umur (tahun) } \\
\hline $40-49$ & 9 & 10 & \multirow{2}{*}{0,493} \\
\hline $50-60$ & 8 & 7 & \\
\hline \multicolumn{4}{|l|}{ Riwayat hipertensi } \\
\hline Ada & 11 & 12 & \multirow[t]{2}{*}{0,40} \\
\hline Tidak ada & 6 & 5 & \\
\hline \multicolumn{4}{|c|}{ Kebiasaan olah raga } \\
\hline Olah raga & 4 & 7 & \multirow[t]{2}{*}{0,40} \\
\hline Tidak olah raga & 13 & 10 & \\
\hline \multicolumn{4}{|c|}{ Indeks massa tubuh } \\
\hline Normal & 6 & 9 & \multirow[t]{2}{*}{0,493} \\
\hline Obesitas & 11 & 8 & \\
\hline
\end{tabular}

Keterangan: ${ }^{*} \mathrm{p}=$ nilai uji Chi Square

riwayat hipertensi keluarga, tidak melakukan olah raga, dan mengalami obesitas (Tabel 1)

\section{Pengaruh perlakuan terhadap penurunan tekanan darah sistolik}

Pada kelompok perlakuan dengan jus belimbing terdapat selisih rerata tekanan darah sistolik secara signifikan $(p=0,000)$ sebelum dan sesudah perlakuan, sedangkan pada kelompok kontrol tidak ada perbedaan secara signifikan rerata tekanan darah sistolik sebelum

Tabel 2. Pengaruh perlakuan terhadap penurunan tekanan darah sistolik

\begin{tabular}{lcccccccc}
\hline \multicolumn{1}{c}{ Rerata TDS } & Awal & Min & Maks & Akhir & Min & Maks & Delta TDS & ${ }^{*} \mathbf{p}$ \\
\hline $\begin{array}{l}\text { Perlakuan } \\
\mathrm{n}=17\end{array}$ & $155,59 \pm 6,59$ & 135 & 160 & $135,88 \pm 8,52$ & 125 & 145 & $19,71 \pm 7,39$ & 0,000 \\
$\begin{array}{l}\text { Kontrol } \\
\mathrm{n}=17\end{array}$ & $152,32 \pm 8,86$ & 140 & 160 & $147,94 \pm 11,99$ & 130 & 170 & $4,41 \pm 8,639$ & 0,051 \\
\hline
\end{tabular}

Keterangan:

TDS = Tekanan darah sistolik

Min = Minimal

Maks $=$ Maksimal

Delta TDS = Selisih tekanan darah sistolik sebelum dan sesudah perlakuan

${ }^{*} p=$ nilai sig. (2-tailed) paired t-test pada $\alpha=0,05$

${ }^{*} p$ independent t-test $=0,000$

Tabel 3. Pengaruh perlakuan terhadap penurunan tekanan darah diastolik

\begin{tabular}{lcccccccc}
\hline Rerata TDD & Awal & Min & Maks & Akhir & Min & Maks & Delta TDD & ${ }^{*} \mathbf{p}$ \\
\hline $\begin{array}{l}\text { Perlakuan } \\
\mathrm{n}=17\end{array}$ & $96,76 \pm 3,51$ & 90 & 100 & $82,35 \pm 7,73$ & 70 & 70 & $14,41 \pm 8,078$ & 0,000 \\
$\begin{array}{l}\text { Kontrol } \\
\mathrm{n}=17\end{array}$ & $91,76 \pm 6,83$ & 80 & 100 & $90,88 \pm 10,04$ & 95 & 110 & $0,88 \pm 6,670$ & 0,593 \\
\hline
\end{tabular}

Keterangan:

TDD = Tekanan darah diastolik

Min $\quad=$ Minimal

Maks = Maksimal

Delta TDS = Selisih tekanan darah diastolik sebelum dan sesudah perlakuan

${ }^{*} p=$ nilai sig. (2-tailed) paired t-test pada $\alpha=0,05$

${ }^{*} \mathrm{p}$ independent $\mathrm{t}$-test $=0,000$ 
dan sesudah perlakuan $(p=0,051)$. Selengkapnya dapat dilihat pada Tabel 2.

\section{Pengaruh perlakuan terhadap penurunan tekanan darah diastolik}

Tabel 3 menunjukkan terdapat perbedaan rerata tekanan darah distolik secara signifikan antar kedua kelompok perlakuan dengan $p=0,000$. Pada kelompok perlakuan dengan jus belimbing terdapat selisih rerata tekanan darah diastolik secara signifikan $(p=0,000)$ sebelum dan sesudah perlakuan, sedangkan pada kelompok kontrol tidak ada perbedaan secara signifikan rerata tekanan darah sistolik sebelum dan sesudah perlakuan $(p=0,593)$.

\section{Frekuensi kategori asupan natrium, kalium, kalsium dan magnesium selama penelitian}

Asupan natrium, kalium, kalsium, dan magnesium pada kelompok perlakuan dan kontrol tidak terdapat perbedaan frekuensi kategori asupan dengan $p>0,05$. Pada kedua kelompok sebagian besar asupan kalium, kalsium, dan magnesium dalam kategori kurang, sedangkan asupan natriumnya dalam kategori tinggi. Selengkapnya dapat dilihat pada Tabel 4.

\section{Pengaruh perlakuan terhadap penurunan tekanan tekanan darah sistolik dan diastolik setelah dikontrol dengan asupan natrium, kalium, kalsium, dan magnesium}

Pada uji multivariat dengan menggunakan anakova, diperolah hasil bahwa terdapat pengaruh pemberian jus belimbing Demak dan sirup belimbing terhadap penurunan tekanan darah setelah dikontrol dengan asupan natrium, kalium, kalsium, dan magnesium dengan $p<0,05$ (Tabel 5).

\section{BAHASAN}

Hasil penelitian setelah dilakukan perlakuan baik pada kelompok perlakuan dengan jus belimbing dan kelompok perlakuan kontrol, terdapat penurunan rerata tekanan darah sistolik dan diastolik pada kelompok perlakuan dengan jus belimbing secara signifikan sebesar 19,71 \pm 7,39 $\mathrm{mmHg}$ dan 14,41 $\pm 8,08 \mathrm{mmHg}$. Hasil uji independent $t$-test menunjukkan bahwa terdapat perbedaan rerata penurunan tekanan darah sistolik dan distolik antara kelompok perlakuan dan kelompok kontrol secara signifikan ( $p=0,000)$ (Tabel 2 dan 3$)$. Hal tersebut disebabkan karena pada kelompok perlakuan diberikan jus belimbing Demak yang mengandung $425 \mathrm{~g}$ kalium, $11 \mathrm{mg}$ kalsium, 2,8 mg magnesium, dan tidak dilakukan perubahan diit kecuali penambahan konsumsi jus
Tabel 4. Frekuensi kategori asupan natrium, kalium, kalsium, dan magnesium selama penelitian pada dua kelompok

\begin{tabular}{lccc}
\hline Kategori Asupan & $\begin{array}{c}\text { Perlakuan } \\
(\mathbf{n = 1 7})\end{array}$ & $\begin{array}{c}\text { Kontrol } \\
(\mathbf{n = 1 7})\end{array}$ & \multirow{2}{*}{$\boldsymbol{p}^{*}$} \\
\cline { 2 - 3 } & $\mathbf{n}$ & $\mathbf{n}$ & \\
\hline Asupan natrium & & & \\
$\quad$ Normal $(<2300 \mathrm{mg})$ & 2 & 8 & $\mathbf{0 , 5 7}$ \\
$\quad$ Tinggi $(\geq 2300 \mathrm{mg})$ & 15 & 9 & \\
Asupan kalium & & & \\
$\quad$ Kurang $(<3500 \mathrm{mg})$ & 12 & 13 & $\mathbf{1 , 0 0}$ \\
$\quad$ Normal $(\geq 3500 \mathrm{mg})$ & 5 & 4 & \\
Asupan kalsium & & & \\
$\quad$ Kurang $(<800 \mathrm{mg})$ & 11 & 10 & $\mathbf{1 , 0 0}$ \\
$\quad$ Normal $(\geq 800 \mathrm{mg})$ & 6 & 7 & \\
Asupan magnesium & & & \\
$\quad$ Kurang $(<280 \mathrm{mg})$ & 6 & 14 & $\mathbf{0 , 1 5}$ \\
$\quad$ Normal $(\geq 280 \mathrm{mg})$ & 11 & 3 & \\
\hline
\end{tabular}

Keterangan: $p^{*}=$ Fisher's exact test

Tabel 5. Pengaruh perlakuan terhadap penurunan tekanan darah sistolik dan diastolik setelah dikontrol dengan asupan natrium, kalium, kalsium, dan magnesium

\begin{tabular}{ccc}
\hline $\begin{array}{c}\text { TD } \\
(\mathbf{m m H g})\end{array}$ & Delta sistolik & Delta diastolik \\
\hline Perlakuan $(\mathrm{n}=17)$ & & \\
Rerata & 19,71 & 14,41 \\
SD & $\pm 7,39$ & $\pm 8,078$ \\
Kontrol $(\mathrm{n}=17)$ & & \\
Rerata & 4,41 & 0,88 \\
SD & $\pm 8,639$ & $\pm 6,670$ \\
\hline
\end{tabular}

Keterangan : *p Anakova delta sistolik $=0,001$ ${ }^{*}$ p Anakova delta diastolik $=0,009$

belimbing Demak. Hasil uji Fisher's exact test menyatakan bahwa tidak ada perbedaan frekuensi asupan natrium, kalium, kalsium, dan magnesium secara signifikan selama penelitian ( $p>0,05)$ (Tabel 4).

Hasil dalam penelitian ini sesuai dengan penelitian sebelumnya di Semarang tahun 2007, dengan pemberian sumber kalium, kalsium, dan magnesium yang berasal dari jus pepaya, melon, dan semangka, terdapat penurunan tekanan darah sistolik dan diastolik pada ketiga kelompok perlakuan secara signifikan (12). Penelitian yang dilakukan di Philadelphia tahun 2006, menemukan bahwa pada populasi dengan asupan kalium yang adekuat, tekanan darah, dan prevalensi terjadinya hipertensi lebih rendah dibanding dengan populasi yang mengonsumsi kalium yang tidak adekuat (14). Demikian pula penelitian yang dilakukan di Bengkulu, pada lansia dengan asupan kalium lebih dari atau sama dengan 2000 mg mempunyai risiko sebesar 0,24 kali (95\% Cl: 0,074-0,840) dibanding lansia dengan asupan kalium kurang dari 2000 mg setelah dikontrol faktor asupan natrium, riwayat keluarga, stres, asupan lemak, dan status gizi (15).

Mekanisme kalium dalam jus belimbing Demak dalam menurunkan tekanan darah sistolik dan diastolik 
adalah dengan menghambat pelepasan renin sehingga terjadi peningkatan ekskresi natrium dan air. Renin merupakan hormon yang dikeluarkan oleh sel nefron jukstaglomerulus di ginjal sebagai respon terhadap penurunan tekanan darah. Renin beredar dalam darah dan bekerja dengan mengatalisis penguraian suatu protein kecil yaitu angiotensin menjadi angiotensin I yang secara cepat dapat berubah menjadi bentuk aktifnya yaitu angiotensin II dengan bantuan angiotensin converting enzyme (ACE). Angiotensin II berpotensi besar meningkatkan tekanan darah karena bersifat sebagai vasoconstrictor. Selain itu, angiotensin II juga dapat merangsang pengeluaran aldosteron dari glomerulus adrenal yang dapat meningkatkan tekanan darah dengan jalan retensi natrium, sehingga dengan adanya kalium maka retensi natrium dan air menjadi berkurang. Hal tersebut menyebabkan terjadinya penurunan volume plasma, curah jantung, dan tekanan perifer sehingga tekanan darah akan turun. Hilangnya kalium yang kronik berhubungan dengan peningkatan tekanan darah karena peningkatan hormon aldosteron yang berfungsi dalam peningkatan sekresi kalium dan retensi natrium $(14,16,17)$.

Penelitian yang dilakukan di Amerika Serikat tahun 1997 membuktikan bahwa seseorang yang asupan kalsiumnya adekuat, risiko terkena hipertensi lebih rendah dibanding seseorang yang asupan kalsiumnya kurang (18). Peningkatan asupan kalsium yang adekuat menyebabkan keseimbangan serum kalsium yang positif (19). Hal tersebut berhubungan dengan peran kalsium dalam menstimulasi sekresi hormon paratiroid yang berpengaruh terhadap aktivitas neural dan atau hormon vasoaktif bradikardin dan arterial natriuretic peptide secara langsung melalui pengaturan kadar serum kalsium sehingga asupan kalsium berhubungan negatif dengan tekanan darah yang tinggi. Kalsium dapat meningkatkan ekskresi urin dengan jalan mengaktifkan vasoaktif bradikardin yang merupakan vasodilator potensial angitensin converting enzyme (ACE) sehingga angiotensin I tidak akan berubah menjadi angiotensin II. Hal itu menyebabkan penurunan tekanan darah. Arterial natriuretic peptide merupakan hormon yang diproduksi di atrium jantung dalam merespon peningkatan volume darah, dapat meningkatkan ekskresi garam dan air dari ginjal yang akhirnya dapat menurunkan tekanan darah (14).

Magnesium mempunyai peranan penting dalam upaya pengontrolan tekanan darah dengan cara memperkuat jaringan endotel dan menstimulasi prostaglandin ketika serum magnesium dalam darah tinggi serta dapat meningkatkan penangkapan glukosa sehingga mampu mengurangi resistensi insulin (14). Peningkatan resistensi insulin dapat meningkatkan kadar katekolamin dan reabsorpsi natrium dalam ginjal sehingga tekanan darah meningkat $(16,17)$. Hasil penelitian yang dilakukan di Rotterdam pada tahun 1994 menunjukkan bahwa peningkatan $20 \mathrm{mmol}$ asupan magnesium setiap hari dapat menurunkan tekanan darah diastolik $3,4 \mathrm{mmHg}$ (20). Berbeda dengan hasil penelitian di Bengkulu yang menunjukkan bahwa asupan magnesium lebih dari atau sama dengan $300 \mathrm{mg}$ dan asupan magnesium kurang dari $300 \mathrm{mg}$ tidak berpengaruh terhadap kejadian hipertensi esensial $(p>0,05)$. Namun, meskipun tidak signifikan secara statistik jika dilihat dari OR asupan magnesium merupakan faktor risiko kejadian hipertensi esensial pada lansia (OR = 1,60; 95\% Cl: 0,68-3,99) (15).

Padakelompok perlakuan kontrol dengan menggunakan sirup belimbing, didapat hasil bahwa tidak ada perbedaan secara signifikan rerata tekanan darah sistolik dan diastolik sebelum dan sesudah perlakuan $(p=0,051)$. Penurunan tekanan darah sistolik dan diastolik pada kelompok perlakuan kontrol hanya sebesar 4,41 $\pm 8,639 \mathrm{mmHg}$ dan $0,88 \pm 6,670 \mathrm{mmHg}$ (tabel 2 dan 3). Hal ini kemungkinan berhubungan dengan faktor lain yang dapat berpengaruh terhadap penurunan tekanan sistolik dan diastolik pada kedua kelompok yaitu metode pengukuran tekanan darah. Peningkatan atau penurunan tekanan darah berhubungan dengan kondisi sebelum dilakukan pengukuran. Tekanan darah sangat bervariasi tergantung dari keadaan, cara pengukuran, dan alat yang digunakan. Tekanan darah akan meningkat bila diukur dengan menggunakan karet gelang yang terlalu kecil atau sempit, diukur pada kondisi emosi, sedang melakukan aktivitas fisik, stess, dan sebelum diukur mengonsumsi minuman perangsang yang mengandung kafein seperti kopi, teh atau minuman ringan. Tekanan darah akan cenderung turun jika diukur pada saat bangun tidur atau diukur dengan menggunakan karet yang terlalu lebar atau besar. Alat yang digunakan juga akan berpengaruh terhadap hasil pengukuran. Penggunaan sphygmomanometer air raksa dianggap yang paling akurat karena merupakan "standar emas"(16).

Hasil uji multivariat menggunakan anakova diperoleh hasil bahwa terdapat pengaruh pemberian jus belimbing Demak dan sirup belimbing terhadap penurunan tekanan darah sistolik dan diastolik setelah dikontrol dengan asupan natrium, kalium, kalsium, dan magnesium selama penelitian. Asupan asupan natrium, kalium, kalsium, dan magnesium mempengaruhi terjadinya penurunan rerata tekanan darah sistolik dan diastolik pada kelompok perlakuan maupun kelompok kontrol dengan $p>0,05$ (Tabel 4). Hal tersebut dapat berarti bahwa asupan natrium, kalium, kalsium, dan magnesium pada kedua kelompok perlakuan tidak berpengaruh terhadap hasil penurunan tekanan darah pada kelompok perlakuan dengan jus belimbing dan kelompok perlakuan dengan sirup belimbing.

Manfaat yang dirasakan subjek saat mengonsumsi jus belimbing di antaranya buang air besar menjadi lancar, badan terasa lebih segar, dan kepala terasa ringan, terasa buang air kecil setelah beberapa saat mengonsumsi 
jus belimbing, sedangkan subjek yang mengonsumsi sirup belimbing mengaku hanya merasakan rasa segar setelah mengonsumsi sirup belimbing karena rasanya yang enak.

\section{KESIMPULAN DAN SARAN}

Pemberian jus belimbing Demak (Averrhoe Carambola $L$ ) sebanyak 280 gram berpengaruh secara signifikan terhadap penurunan tekanan darah sistolik dan diastolik. Perlu adanya sosialisasi oleh petugas puskesmas di Kecamatan Pedan tentang manfaat jus belimbing untuk menurunkan tekanan darah tinggi dan kandungannya yang dapat menurunkan tekanan darah. Penelitian ini murni dilakukan untuk tujuan ilmu pengetahuan dan tidak terdapat conflict of interest dalam penelitian ini.

\section{UCAPAN TERIMA KASIH}

Penulis mengucapkan terima kasih kepada masyarakat Dukuh Badaran Desa Troketon yang telah bersedia untuk berpartisipasi dalam penelitian ini, teman-teman sejawat yang telah memberi dukungan, dan semua pihak yang telah berperan dalam pembuatan artikel ini.

\section{RUJUKAN}

1. Bangun AP. Terapi jus dan ramuan tradisional untuk hipertensi. Jakarta: PT. Agro Media Pustaka; 2006.115.

2. Dinas Kesehatan Jawa Tengah. Profil kesehatan Jawa Tengah 2005. Dinas Kesehatan Provinsi Jawa Tengah; 2005.

3. Djaja S, Suwandono A, Soemantri S. Pola penyakit penyebab kematian di perkotaan dan pedesaan di Indonesia, studi mortalitas survei kesehatan rumah tangga (SKRT) 2001. Jurnal Kedokteran Trisakti; 2003:22(2).

4. Stapleton A, Fine R. Penatalaksanaan hipertensi. dalam: Handbook of medical treatment (terjemahan). Jakarta: EGC; 1996. 190-2.

5. Mansjoer A. Nefrologi dan hipertensi. dalam: Kapita selekta kedokteran edisi III jilid pertama. Jakarta: Media aes culapius FK UI;1999. 519-22.

6. Zamhir S. Prevalensi dan determinan hipertensi di Pulau Jawa, tahun 2004 [serial online] 2004 [cited 2008 Oct 18]. Avalaible from: URL: HYPERLINK http://www.fkm.ui.ac.id.

7. Vitahealth. Hipertensi. Jakarta: PT.Gramedia Pustaka Utama; 2004. 25-30.
8. Kendalikan stres dan hipertensi, raih produktifitas [editorial] [serial online] 2008 [cited 2008 Oct 20]. Avalaible from: URL: HYPERLINK http://depkes.com

9. Irwan D. Belimbing si buah bintang [serial online] 2001 [cited 2008 Oct 25]. Avalaible from: URL: HYPERLINK http://www.indomedia.com

10. Balai Laboratorium Kesehatan Jawa Tengah. Laporan hasil pemeriksaan jus belimbing Demak. Balai Laboratorium Kesehatan Jawa Tengah; 2008.

11. D Jamy. Hypertension. dalam: Heimburger DC, D Jamy. Handbook of clinical nutrition fourth edition. Mosby Elsevier; 2004. 413-9.

12. Maryani E, Isnawati M. Pengaruh pemberian jus pepaya, jus semangka, dan jus melon terhadap penurunan tekanan darah sistolik dan diastolik [KTI] Semarang: IImu Gizi Universitas Diponegoro; 2007.

13. Dauchet L, Czernichow S. Dietary paterns an blood preasure change over 5-y follow-upin the SU.VI.MAX cohort 1,2,3. Am J Clin Nutr [serial online] 2007 [cited 2008 Jul 21]; 85(6): 1650-56. Available from: URL: HYPERLINK http://www.ajcn.org.

14. ATheodore, Kotchen JM. Nutrition, diet, and hypertension. dalam: Shils ME. Modern nutrition in health and disease tenth edition. Philadelphia: Lippincott Williams and Wilkins; 2006. 1095-102.

15. Riyadi A, Wiyono P, Budiningsari RD. Asupan gizi dan status gizi sebagai faktor risiko hipertensi esensial pada lansia di Puskesmas Curup dan Perumnas Kabupaten Rejang Lebong Propinsi Bengkulu. Jurnal Gizi Indonesia 2007; 4(1): 43-51.

16. Gray HH, Dawkins KD, Morgan JM. Hipertensi. dalam: Safitri A. Lecture notes kardiologi edisi ke empat. Jakarta: Erlangga; 2005. 57-69.

17. Beevers G, Gregory YH, O'Brien E. ABC of hypertension the pathology of hypertension. BMJ [serial online] 2001 [cited $2007 \mathrm{Jul} 28$ ];322:911-6. Avalaible from: URL: http:// www.bmj.com.

18. Carron DA. Role of edequate dietary calcium asupan in the prevention and management of salt-sensitive. Am J Clin Nutr [serial online] 1997 [cited 2008 Jul 21]; 65:712S-6S. Available from: URL: HYPERLINK http:// www.ajcn.org.

19. Feng $\mathrm{J} \mathrm{He}$, MacGregor GA. Beneficial effects of potassium. BMJ [serial online] September 2001 [cited 2008 Oct 25];323:497-501. Available from: URL: HYPERLINK http://www.bmj.org.

20. Geleijnse JM, Witteman JCM. Reduction in blood pressure with a low sodium, high potassium, high magnesium salt in older subjects with mild to moderate hypertension. BMJ [serial online] August 1994 [cited 2008 Oct 25]; 309(6952):436. Available from: URL: HYPERLINK http://www.bmj.org. 